\begin{tabular}{c} 
Volume and Issues Obtainable at Center for Sustainability Research and Consultancy \\
Journal of Business and Social Review in Emerging Economies \\
ISSN: 2519-089X (E): 2519-0326 \\
Volume 3: Issue 1June 2017 \\
CSRC \\
Journal homepage: www.publishing.globalcsrc.org/jbsee \\
\hline
\end{tabular}

\title{
Place Effect on Health Food Consumption Patterns: Among Malaysian Consumers
}

\author{
${ }^{1}$ Farouk Djermani, ${ }^{2}$ Yaty Sulaiman \\ ${ }^{1}$ DBA Scholar, Othman Yeop Abdullah Graduate School of Business (OYAGSB), Universiti Utara \\ Malaysia, Malaysia, frie.sein@gmail.com \\ ${ }^{2}$ School of Business Management, Universiti Utara Malaysia, Malaysia
}

\begin{tabular}{|c|c|}
\hline ARTICLEDETAILS & ABSTRACT \\
\hline $\begin{array}{l}\text { History } \\
\text { Revised format: May } 2017 \\
\text { AvailableOnline: June } 2017\end{array}$ & $\begin{array}{l}\text { Purpose:Healthy foods refer to foods that are safe for consumption, fine in } \\
\text { quality and are nutritious in meeting the principle for sustainability of } \\
\text { health. Recently consumption of healthy food has emerged as alternative } \\
\text { approach for preventing form obesity and chronic diseases, that affecting }\end{array}$ \\
\hline $\begin{array}{l}\text { Keywords } \\
\text { Healthy food, } \\
\text { Consumption Patterns, } \\
\text { Lifestyle, } \\
\text { Place }\end{array}$ & $\begin{array}{l}\text { Malaysia with high threat, in which unhealthy food consumption is now the } \\
\text { leading cause of morbidity and mortality in low and middle-income social } \\
\text { classes. The aim of this paper is to investigate on effect of the variable place } \\
\text { on the consumption patterns of healthy food with mediating effect of } \\
\text { consumer lifestyle. Based on that, this conceptual framework is constructed } \\
\text { of four variables place as independent variables, consumption patterns of } \\
\text { healthy food as dependent variable. Moreover, this research also proposed } \\
\text { consumer lifestyle as mediator. Based on the arguments in the article, three } \\
\text { major hypotheses were developed to refine our understanding of the } \\
\text { consumption patterns. }\end{array}$ \\
\hline
\end{tabular}

(C) 2017 The authors, under a Creative Commons Attribution-

NonCommercial 4.0

Corresponding author's email address: frie.sein@ gmail.com

Recommended citation:Djermani, F., Sulaiman, Y., (2017). Place Effect on Health Food Consumption Patterns: Among Malaysian Consumers. Journal of Business and Social Review in Emerging Economies, 3 (1), 33-38.

DOI:https://doi.org/10.26710/jbsee.v3i1.179

\section{Introduction}

A healthy diet is primarily about dietary diversity consuming a variety of foods across and within food groups to meet energy and essential nutrient requirements. Consumption of a wide variety of whole foods, especially vegetables, fruits, legumes, whole grains and nuts, is particularly important (Bereuter \& Glickman, 2015).

Nowadays, healthy diet is mainly variety of consuming a different foods groups get the important required nutrient and energy. Therefore, consumption of a wide different food groups, particularly vegetables, fruits, legumes, whole grains and nuts, is important (Bereuter \& Glickman, 2015)

Nowadays, the rapid growth of fast food industries in Malaysia during the last decades has added another dimension to the change in food consumption pattern among the Malaysian consumers. Moreover, in Malaysia, the availability of variety of food especially in crowded area may be facing implications out of the eating behaviour(Ali \& Abdullah, 2012a). 
This study is attempting to suggest a construction model on consumption pattern for Malaysian consumer on healthy food. Subsequently, the main factors to be studied are place with its effect on consumption pattern with mediation of consumer lifestyle.

\section{Literature Review}

\subsection{Consumption Patterns}

In economic studies the term "consumption" are defined as purchased food, or some a form of sales data of analysis, relatively to actual dietary intake. Additionally, Stagl's (2005: 90) definition of consumption as "the use by human individuals of goods and services to satisfy some of their needs and wants. 'Goods and services' are often referred to as "commodities"' and Campbell's (1995) one as "any activity involving the selection, purchase, use, maintenance, repair and disposition of any product or service"(Boulanger, 2007).

Food consumption and health habits, in current years have been the main focus of policy makers and researchers to establish healthy and continuous living communities (Agraria,2016).

\subsection{Healthy food}

Healthy food defined as low fat, reduced sugar, high fiber, containing fruits and vegetables, and being prepared using appropriate cooking methods (Anita Eves, Michael Corney, 1998; Kim, Lee, Gon Kim, \& Kim, 2013)

\subsection{Consumer lifestyle}

It refers to the entity that purchases and uses products and services for the purpose of individual or household consumption (Bin \& Dowlatabadi, 2005).

\subsection{Place}

The place or physical distribution place or distribution activities add value to the products by creating time, distance and possession utilities.It includes issues such as distribution channels, market coverage, product inventory, transportation and distribution sites ( Eavani \& Nazari ,2012)

\subsection{Consumer lifestyle and consumption patternsonhealthy food}

There are few studies examined the relations between consumer lifestyle and consumption patterns. The study of Vikas Mittal, Wagner A. Kamakura, \& Rahul Govind (2004), similarly the work of Hawkins, Roupe, and Coney (1981) who examined the consumer lifestyle mediator as and consumption patterns as dependent variable(Hawkins, Roupe, \& Coney, 1981; Mittal, Kamakura, \& Govind, 2004). According to Noraziah Ali1, Mohd Azlan Abdullah (2012), the new living environment and changes of lifestyles has resulted in new arrangement in eating, which was not the case two decades ago. As well as, food businesses grow as the individual capacity to cook and to eat food at home is no longer expected, and it goes that traditional values expecting women to prepare food for the family is not compulsory anymore (Ali \& Abdullah, 2012b). As a result, the practice of eating-out has helped families and individuals to meet their food needs, biologically and socially. Accordingly, the consumer lifestyle has significant relationship with consumption patterns (Norimah et al., 2008). Considering the above discussion, the researcher postulates the following hypotheses:

H1: consumer lifestyle has a positive significant relationship with consumption patterns of healthy food

\subsection{Place and consumption patterns on healthy food}

Correspondently in Kearney (2010) revealed that practical changes in dietary patterns has brought the rate of consumption in the urbanization area to have significant effects on global food supply, markets and trade, which demonstrated the high impact of place as an important factor to the consumption pattern on healthy food, particularly the rise in over-nutrition (Indumathi, N., \& Dawood, 2016; Kearney, 2010).Accordingly, many of the previous studies highlighted the significant relationship between place 
and consumption pattern. Thus, the hypothesis is developed as follow:

H 2: Place has positive significant relationship on consumption patterns of healthy food

\subsection{Place and consumer lifestyle}

Previous literature suggested that place is one of the crucial factors for consumer lifestyle on consumption patterns of healthy food. Moreover, Changes in living arrangements that some college students encounter influence their lifestyle factors (El Ansari, Stock, \& Mikolajczyk, 2012) .However, according Prerapha Taweesuk (2014) brings out the mediation of consumer lifestyle, on the study done about organic food in Thai reported that while food choices are commonplace, they have profound impacts on our health (Prerapha Taweesuk, 2014) .Also, Indumathi and Ayub Khan Dawood (2016) reported that place factors do impact the purchase decision of organic product (Indumathi, N., \& Dawood, 2016). Based on the above discussion, the researcher postulated the following hypothesis:

H3: Place has a positive significant relationship with consumer Lifestyle

\subsection{Mediating of consumer lifestyle between place and consumption pattern of healthy food}

In the model of Hawkins, Roupe, and Coney (1981) who examined the consumer lifestyle mediator as and consumption patterns as dependent variable on coffee consumption according to different geographical factors. Likewise, Chryssohoidis and Krystallis (2005) found that consumers who purchase healthy foods (organic food) place greater importance to internal values such as self-respect and enjoyment of life rather than external values such as belonging (Aslihan Nasir \& Karakaya, 2014). Therefore in some studies place availability has recorded the highest correlation on the consumption of organic food which are easily available in most of the places in Malaysia which is supported by the previous study like Ahmad and Judhi (2008) as results have supported healthy like organic food should be made easily availability via online purchase to the consumers (Faktor et al., 2016). That demonstrated based on the model of Hawkins et al., (1981) the place on health food consumption patterns.

H4: Consumer lifestyle mediates positively the relationship between place consumption patterns.

\section{Research Framework}

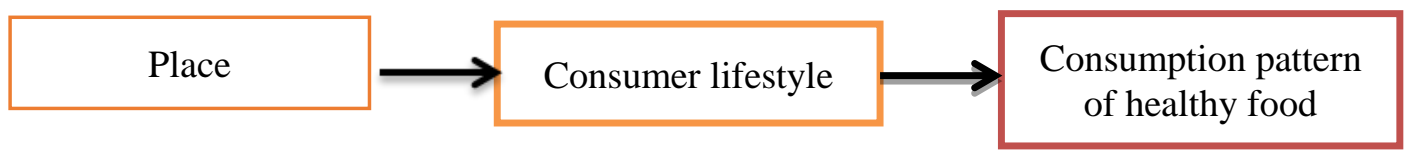

\section{Research Methodology}

\subsection{Population and Sampling size}

The population of this study includes Kedah, Perlis, Perak and Penang states regardless gender, age, education, designation and years of service. The research further states however, that larger samples are in general better than smaller sample but very large sample can lead to erroneous conclusions.

The current population estimated in Malaysia in 2016 is researching 31.7 million people, with growth of 0.5 million people as comparing to the previous year 2015 was 31.2 million individual with growth rate $1.5 \%$ for the same period (Department of Statistics Malaysia, 2016; Malaysia, 2016).The labour work force in Malaysia is defined as for aged group 15 to 64 years.

The unit of analysis in the present research used independents with defined geographical segments for individual consumers aged 18 years 59, around the selected malls. Subsequently, the recommended sample size is 384 according to Krejcie and Morgan, (1970). Then, the total population of 6.570 million people for the fourth states in 2016 : Kedah 2.120, Perlis: 0.250, Perak: 2.480 and Penang 1.720 (Department of Statistics Malaysia, 2016). 
Table 1: Sampling size

\begin{tabular}{llll}
\hline States & Population million (2016) & $\begin{array}{l}\text { Required Sample size } \\
\text { and Morgan (1970) }\end{array}$ & Krejcie \\
\hline Kedah & 2.120 & 384 & \\
Perlis & 0.250 & 384 & \\
Perak & 2.480 & 384 & \\
Penang & 1.720 & 384 & \\
Total & 6570 & 1536 & \\
\hline
\end{tabular}

Source:Krejcie and Morgan (1970)

\section{Conclusion}

The findings of this study can be generalized for Malaysia because it will be conducted in the malls that representing shopping centres. This model has shown some interesting findings which could be applied for utilization in research on a bigger scale to include the whole of Malaysia especially those who actively involved in consumption patterns of Malaysian food habits. Thus, this research study aims to enhance in the different numbers of the studies on healthy food to provide a model on consumption patterns that contribute on Malaysian consumers.

\section{References}

Aleksandra Nikolić, Mirza Uzunović, N. S. (2014). Lifestyle pattern underlying organic and traditional food consumption. British Food Journal, 116(11), $1748-1766$. http://doi.org/http://dx.doi.org/10.1108/VINE-10-2013-0063

Ali, N., \& Abdullah, M. (2012a). The food consumption and eating behaviour of Malaysian urbanites issues and concerns. Malaysian Journal of Society and Space, 3(1), 44-53.

Ali, N., \& Abdullah, M. A. (2012b). The food consumption and eating behaviour of Malaysian urbanites : Issues and concerns, 6(6), 157-165.

Anita Eves, Michael Corney, M. K. (1998). Nutrition knowledge of caterers and constraints to offering more healthy food meals. International Journal of Hospitality Management, 16(4), 403-417.

Aslihan Nasir, V., \& Karakaya, F. (2014). Consumer segments in organic foods market. Journal of Consumer Marketing, 31(4), 263-277. http://doi.org/10.1108/JCM-01-2014-0845

Australian Institue of Health and Welfare. (2012). Australia's food \& nutrition 2012: in brief. Nursing Review (1326-0472). http://doi.org/10.1049/el.2011.3844

Bereuter, D., \& Glickman, D. (2015). Healthy Food for a Healthy World: Leveraging Agriculture and Food to Improve Global Nutrition. Retrieved from http://www.thechicagocouncil.org/publication/healthy-food-healthy-world

Bin, S., \& Dowlatabadi, H. (2005). Consumer lifestyle approach to US energy use and the related CO2 emissions. Energy Policy, 33(2), 197-208. http://doi.org/10.1016/S0301-4215(03)00210-6

Boulanger, P.-M. (2007). Sustainable consumption : a general framework for transition management. Retrieved from http://consentsus-project.pbworks.com/f/Sustainable-

Consumption_BOULANGER.pdf

Castellari, E. (2016). Three Essays on Food Policy and Health Consumption Patterns. Rivista Di Economia Agraria, 1(0035-6190). http://doi.org/10.13128/REA-18672

Department of Statistics Malaysia. (2016). Department of Statistics Malaysia Official Portal. Retrieved 10 April 2017, from https://www.dosm.gov.my/v1/index.php?r=column/cthemeByCat\&cat=106\&bul_id=RUVZRzhLdX JOZXpVaEg4Yno4UldDdz09\&menu_id=bThzTHQxN1ZqMVF6a2I4RkZoNDFkQT09

El Ansari, W., Stock, C., \& Mikolajczyk, R. T. (2012). Relationships between food consumption and living arrangements among university students in four European countries - A cross-sectional study. Nutrition Journal, 11(1), 28. http://doi.org/10.1186/1475-2891-11-28

Faktor, K., Pemasaran, R., Persepsi, T., Pengguna, N., \& Lian, B. (2016). The Effects of Marketing Stimuli Factors on Consumers' Perceived Value and Purchase of Organic Food in Malaysia. Jurnal 
Pengurusan, 47, 119-130. Retrieved from http://dx.doi.org/10.17576/pengurusan-2016-4710\%0AThe

Hawkins, D. I., Roupe, D., \& Coney, K. A. (1981). The Influence of Geographic Subcultures in the United States. ACR North American Advances, NA-08. Retrieved from http://www.acrwebsite.org/search/view-conference-proceedings.aspx? Id=5879

Indumathi, N., \& Dawood, D. (2016). Impact of marketing mix on consumer buying behavior in organic. International Journal of Research in Finance and Marketing, 6(10), 43-54.

Kearney, J. (2010). Food consumption trends and drivers. Philosophical Transactions of the Royal Society B: Biological Sciences, 365(1554), 2793-2807. http://doi.org/10.1098/rstb.2010.0149

Kim, M., Lee, C., Gon Kim, W., \& Kim, J. (2013). Relationships between lifestyle of health and sustainability and healthy food choices for seniors. International Journal of Contemporary Hospitality Management, 25(4), 558-576. http://doi.org/10.1108/09596111311322925

Konopa, L. J., \& Gordon, G. U. Y. G. (2016). American Marketing Association, 33(4), 103-104.

Malaysia, D. of S. (2016). Current Population Estimates, Malaysia , 2014-2016. Retrieved from https://www.statistics.gov.my/index.php?r=column/pdfPrev\&id=OWlxdEVoYlJCS0hUZzJyRUcvZ EYxZz09

Mittal, V., Kamakura, W. A., \& Govind, R. (2004). Geographic Patterns in Customer Service and Satisfaction: An Empirical Investigation. Journal of Marketing, 48(68), 48-62. Retrieved from http://wak2.web.rice.edu/bio/My Reprints/GeographicPatternsinCustomerServiceandSatisfaction.pdf

Norimah, A. K., Safiah, M., Jamal, K., Siti, H., Zuhaida, H., Rohida, S., ... Azmi, M. Y. (2008). Food consumption patterns: Findings from the Malaysian Adult Nutrition Survey (MANS). Malaysian Journal of Nutrition, 14(1), 25-39.

Pandey, P. (2014). Food consumption patterns of Adult population in rural and urban areas of Faizabad district of uttar. International Journal of Science and Research (IJSR), 5(2), 2080-2084.

Prerapha Taweesuk. (2014). The mediation effect of marketing mix strategyon the relationship between consumer lifestyle and repeat purchase in the Thai context, 1-12.

Valley, K., Nor, S., \& Ahmad, B. (2010). Organic Food: A Study on Demographic Characteristics and Factors Influencing Purchase Intentions among Consumers, (2002). 
